$$
\begin{array}{cccc}
\text { S sciendo } & \text { International Conference KNOWLEDGE-BASED ORGANIZATION } \\
\text { Vol. XXVII } & \text { No } 1 & 2021
\end{array}
$$

\title{
MEDIA AS A TRANSMITTER OF INFORMATION PROVIDED BY ARMED FORCES, THE STATE AND TERRORIST ORGANISATIONS IN ARMED CONFLICTS AND TERRORIST ATTACKS
}

\author{
Tomasz BĄK \\ University of Information Technology and Management in Rzeszow, Poland \\ tbak@wsiz.edu.pl
}

\begin{abstract}
The article deals with issues related to the media as a relay of information provided by the armed forces, the state and terrorist organizations, in armed conflicts and terrorist acts. It contains two main subchapters, namely: the first on the role of the media in armed conflicts and terrorist acts, and the second describing the use of media by terrorists. There is no doubt that almost every ongoing armed conflict or terrorist attack can count on a broad media coverage. It is an event that neither news agencies, broadcasters of television news services, nor print media publishers can miss. The text mentions the basic models of behavior of state authorities in this matter of informing the public about events such as warfare or terrorist attack. Forms of providing information from conflict regions or terrorist activities by contemporary journalism have also been described. There was also information about the role of the Internet in the process of reporting the course of the war. An important part of the article is to describe the media strategy in relation to this type of event. The summary concludes on the role of mass media in contemporary armed conflict and the terrorist attack.
\end{abstract}

\section{Keywords: Media, information, armed conflict, terrorist act}

\section{Introduction}

In modern times information is priceless, as we repeatedly find out every day. By definition, it should be useful, easily accessible, relevant, reliable and credible [1]. Of course, these conditions are not always met. The 'mainstream' media does not cover an event through and through. Usually the headline wins out over reliable content. When something specific happens in the world, we do not count on a long description of the situation. It is the title that excites people so much more. When it comes to warfare or terrorist attacks, the media has proved unreliable. Mere slogans and brief descriptions could not suffice. It is important to convey an objective judgement and for the media to avoid indicating any sympathy with the parties to the conflict [2].

Today's mass media broadcasts virtually all important events both nationally and internationally. Reports are transmitted directly from the scene of the event, thus enabling the viewer to participate online in real time. A breakthrough in the broadcasting of events connected with conflicts or terrorist attacks was made by the media after the attack on the World Trade Center on 11 September 2001 [3]. Viewers from practically everywhere in the world could watch the course of the catastrophe and further development of events. The news of the attack on the WTC and the Pentagon went round the world in a flash. On the one hand, the media has 
seized the opportunity to increase its audience, but on the other it has shown an important event with far-reaching consequences in the form of the intervention in Afghanistan and Iraq [4].

\section{The role of the media in armed conflicts and terrorist attacks}

Almost every current armed conflict or terrorist attack can count on extensive media coverage. It is an event that neither news agencies, nor broadcasters of television news services, nor editors of the printed press can ignore. The enormous technological leap that has taken place over the last few years has led to a situation where the average viewer can get the impression of participating in the conflicts being shown, sitting comfortably on a sofa with a remote control in their hand [5].

Since the dawn of the mass press armed conflicts have attracted public interest. Newspaper publishers responded to this demand by sending war correspondents to various corners of the globe, who more or less belatedly reported on the ongoing wars. From the very beginning, those in power used these reports to carry out propaganda activities. The situations during the First and Second World Wars in particular can serve as an example of how states can creatively use information from the front to incite their own public opinion, to control its emotions, for example by reporting on the fate of their own prisoners of war, or on the brutal behaviour of their opponents in general [6].

Over the years we have seen an evolution in the behaviour of state authorities in terms of their openness to journalists' access to the front line of a conflict or the site of a terrorist attack. It is therefore possible to distinguish at least three models of governing behaviour in this matter:

- the first model — full openness to journalists,

- the second model — total control over the flow of information by preventing access to the battlefield,
- the third model — a mixed one access to the battlefield is possible but subject to certain restrictions and strict limitations [7].

Of course, there have often been situations where, under the influence of the media and the subsequent pressure of public opinion, the adopted model of action has been abandoned.

Accounts of armed conflicts were sometimes outdated and not entirely truthful, so there was a need for constant scrutiny of messages from the battlefields.

Today, contemporary journalism dealing with submitting information from areas of conflict or about terrorist activity has taken two forms:

- the first — the classic one - will consist in journalists moving together with line military units conducting warfare or counter-terrorist units operating in the area of terrorist activity;

- the second will be based on the work of journalists in information centres located at operation command centres.

The manner and nature of reporting from the scene of armed conflict has changed with the development of technology and civilisation. Before the advent of electronic media, coverage of the war reached the public with considerable delay. Modern equipment enabled journalists to provide an almost instantaneous feed from the 'battlefield'.

The term 'media war' implies the involvement of modern audio-visual media in armed conflict, frequent 'live' coverage, showing military interventions, bombings, hostage-taking mechanisms. On the other hand, the 'media war' means increased manipulation of the message, surveillance of journalists by the military, limited objectivity dictated by the economic conditions of the media [8].

The spread of the Internet marked another huge breakthrough in the process of reporting on the war. The proof is in the 
broadcasting of the fighting in Kosovo in 1999 [9]. It became possible to show the public events that the warring parties feared would be made public on television and radio.

The mass media 'in the hands' of terrorists has also become a very dangerous tool. With the development of technology and information technology there has been an escalation in the transmission of terrorist acts. The media allows a terrorist attack to be communicated, and also reinforce the sense of threat and fear. Terrorists use the media in two ways. They use their own media, but also the independent media [10]. Military conflict moved into the space of media rivalry between the warring parties many years ago. One success of the terrorists themselves is that television stations around the world are ready to pay millions for interviews with rebel leaders. In addition to powerful financial support, terrorists gain something much more important, namely valuable airtime in the major media corporations of the West.

In the realities of the modern world where access to rapid information is a guarantee, but also a condition for economic, social or political success - the role of the mass media and communication is becoming a key aspect also for the success of terrorist and asymmetric actions.

Unfortunately, media coverage of an attack becomes an 'advertisement' for a terrorist organisation, providing an opportunity to publicise its agenda and 'cause'. In addition, reporting on the course and background of an attack or other major event related to terrorism is a guarantee for the media (for the reasons mentioned above) to increase the level of audience interest. This, in turn, is also of value to terrorists, who aim to capture the attention of as many people as possible and create fear among them [11]. The most effective way to achieve this goal, i.e. to focus the attention of the media (and the public under attack), is in turn to carry out further spectacular actions or to issue a public threat of such actions. In many terrorist attacks in recent years terrorists have skilfully used the media to multiply the scale and social impact of their actions. The media, while formally acting in the name of providing information and showing a picture of the real world, at the same time unwittingly became in such cases a tool of terrorists and a new weapon in their arsenal. The modern mass media - in particular television and the Internet - enables the perpetrators of terrorist actions to achieve the so-called 'theatre effect' when reporting on the course or consequences of such actions.

There is no doubt that terrorist attacks are now increasingly carefully planned to specifically attract media attention. Terrorism today is thus becoming increasingly spectacular and mediaoriented. Through the media(above all television), a single act of violence becomes a public matter. The Internet is no longer just websites, where propaganda materials (proclamations, statements, etc.) are posted, but also multimedia - TV and radio broadcasts and audio/video recordings. Today access to the Internet is possible from laptops or mobile phones. Terrorist groups have long used the Internet for propaganda, and their possibilities for communication and influence through this medium are almost unlimited. The Internet cannot be censored, which makes the power of its message and the possibilities it contains to influence social attitudes much greater than television, where there is still journalistic self-censorship and top-down legal regulations preventing the full scale of a given dramatic event from being presented.

What has not been broadcast on television due to its drastic nature and brutality will be found widely available on the Internet after a short search.

Another popular use of the Internet by Islamists is to spread their own political and ideo-religious propaganda, mainly by publishing recordings of proclamations and statements of their leaders on the Internet. 
By transmitting terrorist proclamations or announcements, the media thus necessarily participates in the intimidation of a given society or group of societies (e.g. in relation to the West as a whole), escalating the level of fear, of insecurity. Such escalation is very often completely out of step with the actual terrorist threat level.

Recent years have shown that thanks to the Western media's uncritical approach to terrorism, terrorists are even able to skilfully create new 'virtual' organisations, with all the 'media hype' and appearances of real activity surrounding them. Another important issue related to the role of the media in the context of terrorism is the mechanism of manipulation of the information itself, transmitted through the media (especially television, but also increasingly the Internet).

Thus, if the media (especially television, which enjoys the greatest power of social influence) gives special prominence to events related to terrorism (even without objective justification for emphasising the importance of this phenomenon at a given time) - most viewers will automatically assume that the topic presented is an important problem. If the media's portrayal of terrorism reaches a certain critical mass and, in addition, the public feels pressure from terrorism from sources other than the media (e.g. a significant proportion of ethnic groups in society commonly associated with terrorists, past terrorist incidents, etc.) - a significant level of intimidation of the population concerned may be achieved.

\section{The use of the media by terrorists}

The relationship between terrorists, the media and the public is presented in Figure 1. It shows that terrorists send three messages through the media:

- to their supporters, whom they reinforce in the belief of their strength;

- to intimidate the public opinion of a country and to draw international attention, thus highlighting their presence;

- 'heroism' in the fight for their goals, against dissenters or other opponents (e.g. political bodies).

The fourth estate is becoming an effective tool in the hands of terrorists [12].

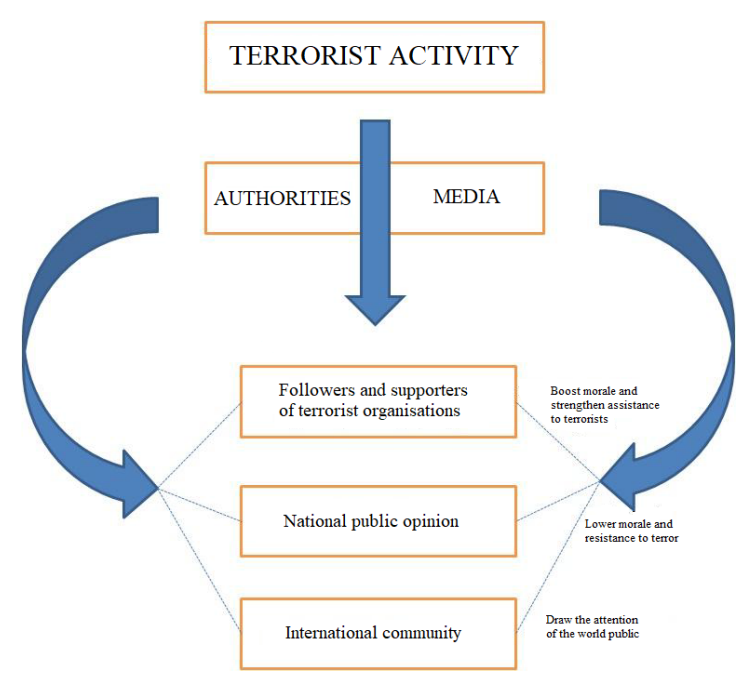

Figure 1. Relationship: terrorist attacksmedia - centres of public opinionauthorities

Source: ICT Papers on Terrorism, The International Policy Institute for Counter Terrorism, Jerusalem 2002, p. 27.

The government's priority role should be cooperation with the media and the construction of a strategy based on education and prevention, conducting campaigns to raise public awareness and explain a phenomenon such as terrorism, reducing fear and ignorance.

The media strategy should include activities such as [13]:

- countering threats including radicalisation and recruitment to terrorism;

- strengthening the will to counter terrorism in a society;

- disseminating reliable information and educating the public on counterterrorism and other threats; 
- facilitating fragmentation of criminal groups and identification of their members.

One form of a dialogue with the public of an educational nature may be a campaign in which the public is informed about the form of potential threats, how to prepare and behave when one has occurred, how to communicate with security services, government actions and their concern for the safety of their citizens. Active propaganda should create public acceptance of the security forces and applied measures, reassurance that the state is in control of the situation, and minimise anxiousness and growing panic. When it is certain that a specific threat, such as a terrorist attack, will happen, it is necessary to notify the public not only of the threat but of the action taken by the government. Explaining the situation to the public in this way could save someone's life. The UK can boast of well-executed campaigns - If you suspect something - report it. It's probably nothing, but [14]...

A very important aspect of the media message is its formulation and choice of words. At present, the word 'terrorism' is overused and popular in the media, and is attributed to people or phenomena that do not bear its hallmarks. Sometimes the media treats certain terms as synonymous, although their meaning carries a different message to the recipient, e.g. guerrilla, terrorist, rebel, war, conflict, crisis. Care in the choice of vocabulary in the message proves to be key in creating the views of the addressees, so it should be used carefully and appropriately to the events that are taking place, and this will help to achieve a higher level of audience confidence [15].

\section{Conclusion}

A pattern of relations between the military and journalists has now been developed. It includes:

- the move after the Vietnam conflict away from complete freedom for journalists to operate during armed conflicts. The price of restrictions and control is access to information for selected circles, broadcasters, titles;

- the activities of the armed forces in the field of winning public opinion for armed conflict are based on passive and active elements;

- passive means making information available to journalists, allowing them to be on the front line under strict conditions;

- active is acquiring journalists, paying for favourable publications, or finally bringing one's own people into the media, for example from psychological warfare units.

The recipients of information, the viewers and readers, therefore need to remember that the information they are dealing with has passed through a strong selection sieve, both of the military and the journalists themselves.

Conclusions have now been drawn on the role of mass media in contemporary armed conflict and terrorist attack:

1. The progressive computerisation and mediatisation of public life is influencing the nature and course of contemporary armed conflicts. The media is used to indoctrinate public attitudes and justify military action.

2. The task of the modern media is not only to report military action, but to actively shape reality, including the media one. The mass media, in broadcasting its messages to the public, relies to a large extent on the use of understatement, over-interpretation, emotionally charged expressions intended to arouse certain social and national attitudes. The concept of truth is in this case deliberately plasticised and inverted by the media.

3. The media is increasingly dependent on the policies of governments and terrorist organisations. The media loses its missionary and controlling character under the influence of political and social pressure, and serves to modify the mood of society. The Bush administration has 
effectively used the media to educate the American public on the prospects of the Iraq conflict and its causes.

4. Terrorist organisations use all possible media to attract new members and seek lucrative sources of funding. The Western media is becoming an arena in which terrorists conduct their propaganda and media campaign. Arab television stations are just as significantly providing airtime to terrorists, more or less unwittingly.

5. The exposure of war images in coverage of executions or terrorist attacks has a brutalising and tabloid sing effect on the mass media. The media portrays violence and bloodshed in order to reach its audience as effectively as possible and to fulfil its duty to report on every aspect of the war effort.

6. Armed conflicts and terrorist attacks became the most important media events of the year and were consistently covered by the world's largest news agencies and television stations. In spite of this significant global media interest in conflicts and attacks, each television station or news agency broadcasts its messages in a different way, and the content of the messages is to a large extent dependent on the politics of the country in which it operates [16].

\section{References List}

[1] Media w sytuacji konfliktu [Media in conflict situations], in: "Roczniki Bezpieczeństwa" ["Security Yearbooks"], Dolnośląska Szkoła Wyższa, http://www.rocznik bezpieczenstwa.dsw.edu.pl/fileadmin/user_upload/wydawnictwo/RBM/RBM_artykuly/ 2006_10.pdf. Accessed 12 December 2014.

[2] A. Kucharczak, Rola mediów w konflikcie batkańskim [The role of the media in the Balkan conflict], Zeszyty naukowe ruchu studenckiego nr. 2 [Scientific Journals of the Student Movement No. 2] (2015).

[3] Media Representations of September 11, edited by S. Chermak, F.Y. Bailey, M. Brown, Praeger Publishers, Westpoint 2003, pp. 4-7.

[4] W.Stankiewicz, Środki masowego przekazu we wspótczesnym konflikcie Zbrojnym casus Iraku $w$ latach 2003-2010 [Mass Media in Contemporary Armed Conflict: the Case of Iraq, 2003-2010], Zeszyty naukowe AON nr. 1(90) [Scientific Journals of the National Defence Academy No. 1(90)] 2013.

[5] Ł. Szurmiński, Media na wojnie - modele relacji wojsko-dziennikarze na przyktadzie konfliktow zbrojnych $w X X i$ XXI wieku [Media at war-models of military-journalist relations on the example of armed conflicts in the 20th and 21st centuries], https://depot.ceon.pl/bitstream/handle/123456789/1149/Media\%20na\%20wojnie\%20$\% 20$ Manipulacja $\% 20 \mathrm{w} \% 20$ mediach....pdf? sequence $=1$

[6] A huge selection of material from different eras on war propaganda activities can be found in the following works: G. S. Jowett, V. O'Donnell, Propaganda and Persuasion, Thousand Oaks 1999, passim; O. Thomson, Easily Led: A History of Propaganda, Sutton 1999, passim.; M. Kunczik, A. Zipfel, Introduction to the Science of Publicism and Communication, Skopje 1998, p. 265-282.

[7] Ł. Szurmiński, Media na wojnie - modele relacji wojsko-dziennikarze na przyktadzie konfliktow zbrojnych $w X X i$ XXI wieku [Media at war-models of military-journalist relations on the example of armed conflicts in the 20th and 21st centuries], https://depot.ceon.pl/bitstream/handle/123456789/1149/Media\%20na\%20wojnie\%20$\% 20$ Manipulacja $\% 20 \mathrm{w} \% 20$ mediach....pdf?sequence $=1$

[8] http://www.dialogi.umk.pl/dezinformacja-konflikt-zatoka-perska.html. Accessed 10 April 2012.

[9] B. Ociepka, op. cit., p. 137. 
[10] L. Dyczewski, Media o terroryzmie i terroryzm o mediach [Media about terrorism and terrorism about media], in: Media masowe... [Mass media...], p. 12.

[11] T. Otłowski, Media - broń w rękach terrorystów? [Media - a weapon in the hands of terrorists?], Biuletyn Opinie nr. 20/2009 [Opinions Bulletin No. 20/2009] .

[12] M. Kwiecińska, Wykorzystanie mediów dla podniesienia bezpieczeństwa, potrzeby $i$ sposoby realizacji [Use of media to enhance safety, needs and implementation], Obronność — Zeszyty naukowe [Defence — Scientific Journals] 3(11)/2014.

[13] Vide T. R. Aleksandrowicz, Medialne aspekty... [Media aspects...], op. cit, p. 36.

[14] Vide: http://content.met.police.uk/Page/Campaigns, Accessed on 9 December 2014.

[15] M. Kwiecińska, Wykorzystanie mediów dla podniesienia bezpieczeństwa, potrzeby $i$ sposoby realizacji [Use of media to enhance safety, needs and implementation], Obronność — Zeszyty naukowe [Defence — Scientific Journals] 3(11)/2014.

[16] W.Stankiewicz, Środki masowego przekazu we współczesnym konflikcie Zbrojnym casus Iraku $w$ latach 2003-2010 [Mass Media in Contemporary Armed Conflict: the Case of Iraq, 2003-2010], Zeszyty naukowe AON nr. 1(90) [Scientific Journals of the National Defence Academy No. 1(90)] 2013. 